\title{
POLA KADERISASI DALAM KEPEMIMPINAN MUSA TERHADAP KEPEMIIMPNAN KRISTEN MASA KINI
}

\author{
Oleh : Pdt. DR. Bastian Salabai, S.Th., M.A., M.Th \\ Ketua Prodi Kepemimpinan Kristen (S2)
}

\begin{abstract}
ABSTRAK
Setiap orang ingin jadi pemimpin, dan setiap pemimpin yang baik harus bisa menyiapkan para pemimpin yang baru dengan cara mengkaderkan orang-orang yang dapat dipersiapkan menjadi pemimpin masa depan. Sebab pemimpin tidak bersifat kekal, karena itu diperlukan para kader-kader terbaik untuk dipersiapkan dengan baik untuk menjadi pemimpin di kemudian hari. Seorang pemimpin juga harus mempunyai visi dan misi yang jelas dengan tujuan agar sebagai pemimpin dapat mencapai suatu tujuan yang jelas dalam masa kepemimpinannya. Dalam Perjanjian Lama Musa telah mempersiapkan Yosua sebagai pemimpin masa depan yang kelak akan menggantikan Musa bilamana Musa tidak lagi menjadi pemimpin. Demikian juga dalam Perjanjian Baru Yesus Kristus telah mempersiapkan muridmurid-Nya sebagai pemimpin masa depan yang siap menggantikan Yesus Kristus bilamana Yesus Kristus tidak lagi menjadi pemimpin dan bersama-sama dengan murid-murid Yesus lagi.
\end{abstract}

\section{Kata Kunci : Pola Kaderisasi, Kepemimpinan}




\section{A. PENDAHULUAN}

Indikator suksesnya seorang pemimpin dalam masa kepemimpinannya adalah jika ia mengkaderkan orang lain untuk menggantikan posisinya dalam suatu jabatan kepemimpinannya. Sebaliknya jika seorang pemimpin sama sekali tidak mengkaderkan orang lain untuk menggantikan posisi jabatannya ia adalah seorang pemimpin yang gagal dalam masa kepemimpinannya. Mengapa kebanyakan para pemimpin masa kini tidak mau mengkaderkan orang lain karena dia takut disaingi dan tidak mau orang lain memegang jabatan yang sedang ia menjabat sebagai pemimpin, ia tidak mau orang lain melebihi dirinya. Ada beberapa faktor yang harus dipikirkan oleh seorang pemimpin adalah bahwa jabatan yang sedang ia jabat adalah tidak kekal ada aturan dan ketentuan yang mengatur tentang lamanya masa jabatan, faktor usia, keberlangsungan oranganisasi pada masa yang akan datang perlu ada yang meneruskan.

Untuk itu marilah kita belajar dari seorang tokoh terhebat dan terbesar dalam Alkitab yang sukses dalam masa kepemimpinannya yaitu Musa. Bagaimana pola kaderisasi dalam masa kepemimpinan Musa terhadap kepemimpinan Kristen masa kini.

\section{B. RIWAYAT HIDUP MUSA}

Musa dalam bahasa Ibrani hv\#m), standar "Mose, Tiberias "Mosse. Musa lahir di Mesir 1527 SM, meninggal di gunung Nebo dataran Moab, tepi Timur sungai Yordan 1407 SM, pada umur 120 tahun. Musa adalah Pemimpin dan Nabi orang Israel yang menyampaikan Hukum Taurat dan menulisnya dalam pentatera/pentateukh (lima kitab Taurat dalam Alkitab Kristen. Ia ditugaskan Allah untuk membawa bangsa Israel keluar dari tempat perbudakan menuju Kanaan tanah perjanjian yang penuh susu dan madu. Nama Musa disebut sebanyak 873 kali dalam 803 ayat dalam 31 buku di Alkitab terjemahan baru.

Arti nama : Orang yang diambil dari Air.

Nama Ayah : Amram, dari suku Lewi

Nama Ibu : Yokhebed dari suku Lewi juga

Nama Anak : 1. Gerzom

2. Eliezer 


$\begin{array}{ll}\text { Nama Saudara Kandung } & : \text { 1. Harun berumur } 12 \text { tahun (Laki-laki) } \\ & \text { 2. Miryam berumur } 3 \text { tahun (Perempuan). } \\ \text { Pekerjaan } & \text { Pengantara Allah, Pemberi Hukum, Nabi, } \\ & \text { Pemimpin bangsa Israel } \\ \text { Tempat lahir } & : \text { Gosyen Mesir } \\ \text { Tempat Meninggal } & : \text { Gunung Nebo, Moab (Yordania Modern } \\ & \text { sekarang) } \\ \text { Umur saat meninggal } & : 120 \text { Tahun }\end{array}$

\section{PENDIDIKAN MUSA}

Setelah Musa berumur 4 tahun maka iapun di bawa kepada puteri Firaun yang mengangkatnya menjadi anaknya. Diberinya nama Musa kepadanya, nama Musa, yang berarti : anak yang ditarik dari sungai Nil atau anak yang ditrik dari dalam air. Di istana itu Musa mendapatkan pendidikan sebagai putera raja Mesir. Ia diberi pelajaran dari segala ilmu pengetahuan orang Mesir (Kis. 7:22); ia mempelajari Ilmu Teologi, ilmu Falak, ilmu pasti, ilmu kedokteran, ilmu bumi, ilmu Hukum dan mata pelajaran lainnya. Sejarah ini memperlihatkan kepada kita dengan terang sekali, bagaimana ajaibnya pimpinan Allah. Musa didik di istana puteri Mesir dan dengan demikian mendapat didikan untuk tugasnya nanti, ia diasuh oleh ibunya yang memberi kepadanya pelajaran pertama dalam agama, sehingga ia tahu bahwa ia adalah orang Israel. Dengan demikian pembebesan orang Israel adalah pekerjaan Allah.

\section{KEPEMIMPINAN MUSA}

Sebelum membahas lebih detail tentang proses kepemimpinan Musa, telebih dahulu melihat pengertian kepemimpinan itu sendiri. Kepemimpinan adalah suatu proses di mana seseorang itu dapat mempengaruhi orang lain atau organisasi di dalam suatu tujuan yang ingin dicapai. Menurut para ahli kepemimpinan adalah mempengaruhi atau mendapatkan pengikut (Jhon C.Maxwel). Dan menurut Yong kepemimpinan adalah bentuk denomisasi lain yang didasari atas kemampuan pribadi yang sanggup mendorong atau mengajak orang 
lain untuk berbuat sesuatu yang bedasarkan penerimaan oleh kelompoknya. Kata kepemimpinan berarti mengakut tugas seorang pemimpin. Sedangkan kata pemimpin bararti mengkut pribadi orang yang memimpin. Orang lain dapat mengikuti seorang pemimpin sejauh mana pemimpin itu mempunyai pengaruh untuk memimpin orang yang dipimpinya.

Musa adalah pemimpin dan pendiri bangsa Israel. Musa sebagai pemimpin besar yang ditulis dalam Perjanjian Lama. Sistem pemerintahan Musa pada waktu itu adalah sistem pemerintahan Teokrasi. Teokrasi adalah bentuk pemerintahan di mana prinsip-prinsip Ilahi memegang peran utama. Kata "Teokrasi," berasal dari bahasa Yuanani Teokratia (Teokratia). Kata Qeos (Theos) artinya "Tuhan," dan kratein (kratein) "memerintah." Pemerintahan Teokrasi adalah sistem pemerintahan yang menjunjung dan berpedoman pada prinsip Ilahi. Dalam kepemimpinan Musa hanya melaksanakan apa yang menjadi petunjuk dan perintah Allah kepadanya.

\section{Panggilan Musa}

Bangsa Israel mengalami perbudakkan dan sangat menderita karena kerja paksa dan tindakan kekejaman yang dilakukan raja Mesir kepada mereka. Karena perbudakan itu mereka berseru-seru, mereka minta tolong. "Lama sudah itu matilah raja Mesir. Tetapi orang Israel masih mengelu karena perbudakan dan mereka berseru-seru sehingga teriak mereka meminta tolong karena perbudakan itu sampai kepada Allah. Allah mendengar mereka mengerang, Lalu Ia mengingat kepada perjanjian-Nya dengan Abraham, Isak, dan Yakub. Maka Allah melihat orang Israel itu dan Allah memperhatikan mereka (Kel. 2:23-25).

Teriakan minta tolong karena kesengsaraan itu sampai kepada Allah dan Allah mendengar seruan mereka dan Allah menaruh perhatian yang sungguh kepada bangsa Israel "Dan TUHAN berfirman: $\mathrm{Aku}$ telah memperhatikan dengan sungguh kesengsaraan umat-Ku di tanah Mesir, dan Aku telah mendengar seruan mereka yang disebabkan oleh pengerah-pengerah mereka, ya Aku mengetahui penderitaan mereka (Kel. 3:7). Dengan penderitaan itu Allah mau membebaskan Israel dari tempat perbudakan di Mesir, sehingga Allah memanggil Musa untuk melaksanakan tujuan Allah tersebut. 
Tuhan memanggil Musa dan menugaskannya untuk memimpin bangsa Israel keluar dari tempat perbudakan di Mesir untuk pergi ke negeri Perjanjian yaitu Kanaan, negeri yang penuh dengan susu dan madu. "Jadi sekarang pergilah, Aku mengutus engkau kepada Firaun untuk membawa umat-Ku, orang Israel keluar dari Mesir (Kel. 3:10). Disi kita bisa melihat bahwa kepemimpinan Musa berawal dari panggilan Tuhan. Kepemimpinan Musa bersumber pada panggilan Ilahi. Allah memanggil seseorang untuk menjadi sorang pemimpin, Allah yang memanggil itu, Allah yang menyertai, dan memperlengkapi pemimpin yang dipilih dan dipanggil.

\section{Visi Musa}

Visi Musa adalah "Umat Israel yang bebas dan dan sejahtera sebagai bangsa pilihan Allah. Lahirnya visi dalam diri seorang pemimpin adalah berdasarkan suatu pergumulan tentang suatu situasi dan keadaan yang dialami di suatu daerah. Visi tersebut kemudian disampaikan kepada orang lain sehingga ikut terlibat dalam melaksanakan visi tesebut sampai tercapai.

Jika kita memperhatikan visi Musa tersebut tentunya mengingatkan kita kepada masa kecilnya sampai ia menempuh pendidikan dengan bebagai ilmu yang tentunya merupakan pengalaman dan mempersiapkan Musa untuk bangkit dan merespon panggilan dan perintah Allah untuk memimpin bangsanya yaitu Israel keluar dari perbudakan di Mesir dan menikmati sejahtera di negeri penjanjian yang penuh dengan susu dan madu yaitu Kanaan.

Secara Teologis, semua manusia di dunia ini telah bebuat dosa dan telah kehilangan kemuliaan Allah. Musa dipanggil oleh Allah untuk melaksanakan tugas tersebut menggambarkan Yesus mengorbankan diri-Nya di kayu salib agar semua umat manusia mendapat pengampunan dosa dan setiap orang yang percaya kepada-Nya sebagai Tuhan dan Juruselamat pribadi mendapat keselamatan dan hidup yang kekal. Itulah sebabnya Yesus Pemimpin Agung, memiliki Visi, berdasarkan Injil Matius 28:18-20, yaitu Menjadikan semua bangsa murid Kristus. 


\section{Misi Musa}

Misi Musa adalah "Membawa bangsa Israel keluar dari perbudakan di Mesir dan mengalami sejahtera di negeri Kanaan." Berdasarkan panggilan Allah yang sangat jelas kepada Musa, Allah menaruh misi-Nya dalam diri Musa yang telah dipanggil sebagai pemimpin Israel tersebut untuk melaksanakan misi Allah. Tuhan memberi misi kepada Musa yaitu untuk membawa umat Tuhan keluar dari Mesir, oleh karena seruan Israel telah sampai kepada Allah "Sekarang seruan Israel telah sampai kepada-Ku, juga telah kulihat betapa kerasnya orang Mesir menindas mereka. Jadi sekarang pergilah, $\mathrm{Aku}$ mengutus engkau kepada Firaun untuk membawa umat-Ku orang Israel keluar dari Mesir," (Kel. 3:9-10).

Setiap orang yang dipanggil Tuhan untuk memimpin mesti melihat dan menyadari misi yang Tuhan embankan. Tanpa misi, kepemimpinan menjadi tanpa arah. Dalam tugas kepemimpinannya, seorang pemimpin harus jelas dengan misinya sehingga ia dapat mengarahkan dan membawa pengikutnya berjalan bersamanya sampai pada penggenapan misi itu. Banyak pemimpin yang memulai dengan misi yang jelas namun kemudian berubah santai. Jika tidak ada lagi misi, sebaiknya pemimpin mengundurkan diri agar Tuhan dapat memakai orang lain yang memiliki misi yang jelas.

Sebagai tindakan realisasi dari misi Allah yang telah ditaruh dalam hati Musa tersebut, Allah memerintahkan Musa menghadap Firaun agar ia melepaskan bangsa Israel keluar dari Mesir untuk pergi mengadakan perayaan di padang gurun. "Kemudian Musa dan Harun pergi menghadap Firaun, lalu berkata kepadanya: Beginilah Firman Tuhan, Allah Israel: Biarkanlah umat-Ku pergi untuk mengadakan perayaan bagi-Ku di padang gurun (Kel. 5:1). Seklipun pada waktu itu Firaun tidak mengijinkan umat Israel untuk pergi beribadah di padang gurun. Sekalipun demikian kerasnya Firaun, misi Allah ini tetap dan harus dilaksanakan oleh Musa. Allah tidak terpengruh dengan kerasnya Firaun. Ia mengutus Musa untuk pergi menghadap Firaun. "Pergilah menghadap, katakanlah Firaun, raja Mesir, bahwa ia harus membiarkan orang Israel pergi dari negerinya (Kel. 6:10). Misi yang jelas dan terus membuat seorang pemimpin tetap teguh dan pantang menyerah kepada keadaan dan situasi apapun sampai apa yang menjadi misinya harus sampai menjadi kenyataan. Misi Musa tersebut sama dengan misi Tuhan Yesus dalam Injil Matius 28:18-20, "mengutus dua belas murid 
untuk pergi memberitakan Injil dan memenangkan semua manusia di dunia ini menjadi murid Kristus. Itu adalah misi yang diberikan oleh Yesus kepada murid-murid-Nya. Misi Yesus Kristus sangat jelas yakni pergi jadikan semua orang menjadi murid Yesus dengan cara bertobat dan percaya kepada Yesus Kristus.

Seorang pemimpin adalah orang yang memiliki Visi dan Misi yang jelas. Seorang pemimpin yang memiliki visi dan misi yang jelas agar ia dapat memimpin umat atau rakyat yang dipimpinya sesuai dengan tujuan yang ingin dicapai. Jika seorang pemimpin tidak memiliki visi dan misi yang jelas bagaimana mungkin ia dapat memimpin umat yang ada dalam kepemimpinannya dengan baik. Amsal 29:18,"Bila tidak ada wahyu, menjadi liarlah rakyat." Jika seorang pemimpin tidak memiliki visi dan misi yang jelas ia tidak bisa memimpin rakyat yang dipimpinnya dengan baik. Sebab rakyat yang dipimpin hanya terarahkan dengan baik melalui visi dan misi pemimpinnya agar dapat mencapai suatu tujuan.

Seorang pemimpin harus mempunyai visi dan misi. Jika sorang pemimpin tidak mempunyai visi dan misi bagaimana ia dapat mengarahkan orang yang dipimpinnya untuk mencapai tujuan yang ingin dicapai. Karena visi adalah arah, jalan yang dilalui. Seorang pemimpin adalah seorang yang tahu jalan yang mau dilalui. Kalau pemimpin sendiri tidak tahu jalan yang mau dialui, ibarat orang buta memimpin orang buta. Pemimpin adalah seorang yang tahu arah atau jalan yang akan dilalui.

\section{E. POLA KADERISASI DALAM KEPEMIMPINAN MUSA}

Defenisi kaderisasi: Proses atau cara melatih dan membentuk seseorang dipersiapkan dengan berbagai keterampilan dan disiplin ilmu sehingga dia memiliki kemampuan yang di atas rata-rata orang umum yang berfungsi membantu tugas menjadi pemimpin sebuah organisasi atau kelompok masyarakat. Kaderisasi juga beberti: Proses, cara, mendidik atau membentuk seseorang menjadi kader. Orang yang dikaderkan berarti orang yang telah dilatih dan dipersiapkan dengan bebagai keterampilan dan disiplin ilmu. Definisi kata "Pola" bararti: Gambar yang dipakai untuk contoh atau sistem cara kerja. Pola sangat 
penting untuk menghasilkan produk barang jadi yang baru sehingga dapat dipakai sesuai dengan aslinya. Demikian juga untuk membentuk pemimpin baru harus dibentuk dan dipersiapkan untuk melaksanakan kepemimpinan selanjutnya. Pola kaderisasi dalam kepemimpinan Musa adalah :

\section{Memilih Pemimpin Yang Memenuhi Kualifikasi Pemimpin}

Persyaratan memilih orang-orang yang mendampingi Musa dalam memimpin bangsa Israel. Musa diperintahkan Allah untuk memilih orang-orang untuk mendampinginya dan membantu menanggung beban dalam memimpin bangsa Israel. Mereka yang dipilih untuk mendampingi dan membantu Musa dalam memimpin Israel harus memenuhi persyaratan yaitu orang yang takut dan hormat kepada kepada Allah (Kel. 18:21), konsisten menepati janji mereka, berpegang pada perkataan mereka dan berintegritas. Yitro mertua Musa berkata kepada Musa "Engkau akan menjadi sangat lelah, baik engkau baik bangsa yang besar yang beserta engkau ini; sebab pekerjaan ini terlalu berat bagimu, takan sanggup engkau melakukannya seorang diri saja. Disamping itu carilah dari seluruh bangsa itu orang-orang yang cakap dan takut akan Allah, orang yang dapat dipercaya, dan yang benci kepada pengajaran suap; tempatkanlah mereka diantara bangsa itu menjadi pemimpin seribu orang, pemimpin seratus orang, pemimpin lima puluh orang, dan pemimpin sepuluh orang (Kel. 18:18, 22). Para pemimpin yang akan dipilih Musa tersebut haruslah di tempatkan diantara bangsa Israel sesuai dengan jumlah umat, kebutuhan, dan kemampuan pemimpin itu sendiri. Musa mendengarkan perkataan mertuanya itu dan dilakukannyalah segala yang dikatakannya. Dari seluruh orang Israel Musa memilih orang-orang cakap dan mengangkat mereka menjadi kepala atas bangsa itu, menjadi pemimpin seribu orang, pemimpin seratus orang, pemimpin lima puluh orang dan pemimpin sepuluh orang (Kel. 28:24-25).

\section{Melatih Kader Pemimpin}

Selama masa kepemimpinan Musa sebagai pemimpin besar bangsa Israel, Musa memiliki seorang asisten pribadi yang bernama Yosua. Yosua sangat setia mengikuti Musa dalam melaksanakan 
kepemimpinannya kepada bangsa Israel. Yosua melihat semua apa yang dilakukan oleh Musa kepada bangsa Isael. Pengkaderan Musa tersebut berlangsung selama 40 tahun pada waktu Allah menghukum Israel di Padang Gurun. Untuk menumbuhkan pohon perlu berbulanbulan bahkan tahun, untuk membangun gedung perlu tahunan, namun untuk membangun karakter seseorang jauh lebih lama, perlu puluhan tahun. Tuhan mempersiapkan Musa selama 40 tahun sebelum akhirnya memanggil untuk memimpin bangsa Israel keluar dari Mesir. Demikian juga Yosua, Tuhan menghukum bangsa Israel mengembara di padang gurun selama 40 tahun, dan selama itulah Yosua diam-diam dipersiapkan Tuhan dengan rajin membantu Musa. Firman Tuhan mencatata ujian akhir terhadap pribadi Yosua selama 40 tahun yang sangat lama tersebut hanyalah dengan satu kalimat pendek Yosua adalah orang yang mengikut Tuhan dengan sepenuh hati.

\section{Melibatkan Kader Dalam Tugas Kepemipinan}

Musa memberi tugas kepada dua belas orang pengintai untuk mengintai kota Kanaan, termasuk di dalamya Yosua dan Kaleb. Peranan yang lebih signifikan adalah Yosua bersama dengan Kaleb adalah hanya dua mata-mata yang beriman setelah kembali dari tugas memeta-matai tanah Kanaan. Kisah tersebut sudah lebih memberikan kita gambaran kepahlawanan, keberanian, dan juga ketegaran iman Yosua. Yosua dan Kaleb adalah hanya dua mata-mata yang beriman setelah kembali dari tugas memata-matai tanah Kanaan. Selain dari itu Yosua kerap dianggap hanya "sekedar," asisten pribadi yang menemani Musa kemanapun Musa pergi. Namun setelah kepemimpinan Musa berakhir, dan dilanjutkan oleh Yosua. Alkitab memberitakan segala kisah kepemimpinan Yosua.

Musa menyuruh dua belas orang pengintai termasuk Yosua dan Kaleb untuk mengintai kota Kanaan dan harus melapor kembali hasil pengintaian tersebut. "Maka Musa menyuruh mereka untuk mengintai tanah Kanaan, katanya kepada mereka"pergilah dari sini ke tanah Negeb dan naiklah ke pegunungan, dan amat-amatilah bagaimana keadaan negeri itu." (Bil. 13:1-18). Musa melibatkan Yosua dan Kaleb dalam tugas mengintai tanah Kanaan. Sebgai seorang pemimpin tidak hanya memilih, dan melatih kader penerus kepemimpinan tetapi lebih daripada itu harus melibatkan mereka dalam melaksanakan tugas yang 
harus mereka kerjakan. Dengan cara seperti kader pemimpin tersebut sudah benar-benar siap untuk melaksanakan tugas jika kemudian hari dipercayakan sebagai pemimpin.

Sebagai kader yang mendapat kepercayaan untuk melaksanakan tugas harus kembali melaporkan hasil dari tugas yang telah dipercayakan kepadanya untuk dikerjakan. Yosua dan Kaleb kembali menceritakan hasil pengintaian kepada Musa. "Mereka menceritakan kepadanya "Kami sudah masuk ke negeri kemana kau suruh kami dan memang negeri itu berlimpah-limpah susu dan madunya dan inilah hasilnya (Bil. 13:27).

\section{Memberi Tugas Kepemimpinan Kepada Pemimpin Baru}

Setelah Musa sudah tua dan berumur seratus dua puluh tahun dan tidak bisa melakukan tugas memimpin bangsa Israel, secara terbuka di depan bangsa Israel Musa harus mengumumkan seorang yang akan menggantikan dirinya sebagai pemimpin yang melajutkan kepemimpinannya. "Kemudian pergilah Musa mengatakan segala perkataan ini kepada seluruh orang Israel. Berkatalah ia kepada mereka "Aku sekarang berumur seratus dua puluh tahun; aku tidak dapat giat lagi, dan TUHAN telah berfirman kepadaku: Sungai Yordan ini tidak akan kau seberangi. TUHAN Allah Dialah yang akan menyeberang di depan-Mu. Dialah yang akan memunahkan bangsa-bangsa itu dari padamu, sehingga engkau dapat memiliki negeri mereka, Yosua dialah yang akan menyeberang di depanmu, seperti yang difirmankan TUHAN (Ul. 31:1-3).

Sesudah Musa hamba TUHAN itu mati, berfirmanlah TUHAN kepada Yosua bin Nun, abdi Musa itu, demikian: "Hamba-Ku Musa telah mati; sebab itu bersiaplah sekarang, seberangilah sungai Yordan ini, engkau dan seluruh bangsa ini, menuju negeri yang akan Kuberikan kepada mereka, kepada orang Israel itu. Setiap tempat yang akan diinjak oleh telapak kakimu Kuberikan kepada kamu, seperti yang telah Kujanjikan kepada Musa (Yos. 1:1-4).

Tongkat estafet kepemimpinan dari Musa memimpin bangsa Israel secara resmi telah diberikan kepada Yosua abdi Musa karena Yosua telah memenuhi kwalifikasi sebagai seorang yang layak menjadi pemimpin berdasarkan semua proses yang dilewati oleh Yosua dan Tuhan Allah telah menyetujuinya agar Yosua melanjutkan 
kepemimpinan Musa untuk memimpin bangsa Israel masuk ke tanah Kanaan sesuai dengan janji Allah kepada Musa dan bangsa Israel.

\section{F. KEPEMIMPINAN KRISTEN MASA KINI}

Kepemimpinan Kristen masa kini lebih cenderung kepada kepemimpinan modernisasi yaitu kepemimpinan yang sudah banyak terpengaruh dengan kemajuan teknolgi dan IPTEK yang sangat mempengaruhi pola pikir dan kepribadian pemimpin. Hal tersebut membuat para pemimpin masa kini tidak memikirkan pentingnya pengkaderan pemimpin baru yang disiapkan untuk menjadi pemimpin pada masa yang akan datang. Pemimpin masa kini hanya memikirkan masa jabatannya saja dan bagaimana memanfaatkan kesemapatan masa jabatannya tersebut untuk kepentinggan diri sendiri.

Pemimpin masa kini harus melaksanakan salah satu tugas penting yaitu mengkaderkan orang lain untuk melanjutkan tongkat estafet kepemimpinan agar ada pemimpin baru yang dapat melanjutkan kepemimpinannya pada masa yang akan datang. Kepemimpinan tidak dinilai dari hasil saja, namun Alkitab juga mengajarkan bahwa proses pembentukan seorang pemimpin begitu penting. Apakah kita sadar atau tidak sadar kita sedang diproses oleh Tuhan untuk melaksanakan maksud-Nya dalam kehidupan kita sehari-hari.

\section{Memilih Staf Yang Terbaik}

Di dalam sebuah instasi atau sebuah lembaga kemasyarakatan pasti ada staf yang secara oprasional melaksanakan pekerjaan administrari setiap hari. Sebagai seorang pemimpin yang baik harus memperhatikan dan menilai kinerja dari setiap staf atau karyawan yang melaksanakan tugas. Karena dalam penilai tersebut bisa kelihatan staf atau karyawan mana yang terbaik dalam melaksanakan tugas dengan baik. Dari penilaian tersebut pilihlah beberapa orang yang terbaik untuk dilatik sebagai kader pemimpin yang akan melanjutkan kepemimpin lembaga tersebut selanjutnaya.

Tentunya pemilihan staf yang dilakukan oleh seorang pemimpin di lembaga yang dipimpinnya tidak hanya melalui satu segi, tetapi harus melalui berbagai hal mulai dari kesetiaan, loyalitas kepada pemimpin, 
kejujuran, kehidupan rohani, sosial, kemampuan individu, kecakapan, kinerja, serta dapat dipercaya. Sebab di zaman era globalisasi seperti sekarang orang lebih percaya kepada apa yang mereka lihat daripada apa yang mereka dengar. Untuk teori semua orang bisa tetapi praktek belum tentu semua oprang bisa.

\section{Melatih Kader Pemimpin Baru}

Setelah memilih staf yang terbaik berilah mereka pelatihanpelatihan dengan cara berikan tanggung jawab dalam melaksanakan beberapa pekerjaan selama beberapa jangka waktu sesuai dengan volume pekerjaan tersebut sampai selesai dikerjakan dan memberi laporan pertanggung jawaban yang jelas terhadap pekerjaan tersebut kepada pemimpin.

Jika pada suatu hari pemimpin melaksanakan tugas keluar dan tidak ada di tempat tugas, delegasikan tugas kepemimpinan selama pemimpin tidak ada di tempat dengan memberi surat tugas sebagai pejabat sementar. Setelah pemimpin sudah kembali berada di tempat tugas maka pejabat sementara membat laporan pertanggung jawaban tentang tugas yang telah dilaksnakan sebagai pejabat sementara selama pemimpin tidak berada di tempat tugas sesuai dengan surat tugas yang telah diberikan kepadanya.

Selain itu pemimpin memberi kepercayaan kepada kader pemimpin tersebut untuk mewakili pemimipin untuk menghadiri acara sesuai dengan undangan yang diberikan kepada lembaga atau pemimpin lembaga tersebut. Pemimpin harus melakukan hal-hal tersebut kepada kader pemimpin selama menjabat sebagai pemimpin sehingga kader pemimpin tersebut benar-benar siap untuk melanjutkan kepemimpin lembaga tersebut selanjutnya. Sebab tanpa adanya kaderisasi maka lembaga akan mengalami kebingungan bilamana orang tersebut tidak lagi menjadi pemimpin.

\section{Melibatkan Kader Dalam Tugas}

Selama masa kepemimpinan seorang pemimpin harus melibatkan seorang yang dikaderkan dalam tugas yang dilaksanakan oleh pemimpin tersebut. Dengan melibatkan kader pemimpin dalam tugas seperti itu terus menerus, maka kader tersebut terbiasa dan mempunyai 
pengalaman sehingga pada suatu ketika tiba saatnya untuk dia diberi kewenangan untuk menjadi pemimpin dia sudah siap melaksanakan tugas dengan baik. Selain itu juga jika suatu waktu pemimpin keluar melaksankan tugas keluar harus mendelegasikan tugas kepemimpinannya kepada kader tersebut untuk menggantikannya melaksanakan tugas kepemimpinan selama pemimpin devinitif tidak berada di tempat dengan memberikan surat keputusan pelaksana tugas harian.

\section{Memberikan Jabatan Dan Kepemimpinan Kepada Pemimpin Baru}

Setelah melalui proses pengkaderan yang panjang, maka pasti kader tersebut sudah siap baik pribadi, mental, kemampuan memimpin. Maka setelah pemimpin mengakhiri masa jabatannya ia menyerahkan tugas kepemimpinannya kepada pemimpin yang baru untuk melanjutkan kepemimpinan dalam lembaga tersebut. Pemimpin lama harus menyerahkan tugas kepada pemimpin baru tanpa ragu tetapi harus menyerahkan tugas kepemimpinan tersebut dengan iklas dan penuh kepercayaan kepada pemimpin baru dan jangan sampai terkesan melepas kepala tetapi masih memegang ekor kepemimpinan.

\section{G. KESIMPULAN}

Dari semua penjelasan di atas, dapat diberi kesimpulan sebagai berikut:

\section{Tugas Seorang Pemimpin Kristen}

Seorang pemimpin Kristen adalah seorang yang melaksanakan tugasnya berdasarkan akan panggilan Allah. "Kepemimpinan Kristen didasarkan atas premis utama bahwa Allah di dalam kehendak-Nya yang sempurna yang berdaulat telah menetapkan serta memilih setiap pemimpin Kristen kepada pelayanan memimpin. Premis ini ditegaskan oleh J. Robert Clinton yang mengatakan: "Pemimpin Kristen adalah 
seseorang yang telah dipanggil Allah sebagai PEMIMPIN yang ditandai oleh:

1. Kapasitas memimpin.

2. Tanggung jawab pemberian Allah UNTUK.

3. Memimpin suatu kelompok umat Allah (gereja).

4. Mencapai TUJUANNYA bagi serta melalui kelompok ini.

Dengan panggilan tersebut menjadi dasar yang kuat bagi pemimpin tersebut sehingga ia dapat melaksanakan tugas panggilannya dengan semangat, dan terus maju melaksanakan tugasnya dengan baik dan lancar sampai sukses.

\section{Pengkaderan}

Pengkaderan adalah salah satu tugas terpenting yang harus dilaksanakan oleh seorang pemimpin Kristen. Karena salah satu indikator suksesnya seorang pemimpin Kristen dalam masa tugasnya adalah jika ia berhasil mengkaderkan calon pemimpin baru untuk mengggantikan dirinya melanjutkan tongkat estafet kepemimpinannya pada masa selanjutnya setelah masa bakti pemimpin lama berakhir.

\section{Kepemimpinan Kristen Masa Kini}

Bagi pemimpin Kristen masa kini, dapat mempelajari pola kepemimpinan dan cara pengkaderan yang yang telah dilakukan oleh pemimpin terbesar di dalam Alkitab Perjnjian Lama yaitu Musa. yaitu dalam melaksanakan tugas sebagai pemimpin Kristen harus dilandasi dengan hidup takut akan Tuhan. Melaksanakan tugas yang telah diberikan dengan rasa tanggung jawab dan benar-benar bekerja dalam konteks pelayanan yang sedang dilaksanakan.

Selama melaksanakan tugas harus mempersiapkan kader pemimpin yang baru. Pemimpin yang lama jangan takut disaingi, tetapi jika sudah masa jabatan selesai harus dengan rela dan tulus hati melepaskan tugas dan jabatan kepada pemimpin baru untuk melanjutkan tugas kepemimpinan itu selanjutnya. Seorang pemimpin Kristen yang mengkaderkan pemimpin baru untuk melanjutkan tugas kepemimpinan selanjutnaya adalah seorang pemimpin yang sukses dalam masa kepemimpinannya. Jika ia sudah sukses dalam masa kepemimpinannya 
ia pasti diingat, dikenang oleh banya orang disepanjang masa. Sebab masyarakat yang dipimpinnya adalah umat ciptaan Allah.

\section{DAFTAR PUSTAKA}

Alkitab. Lembaga Alkitab Indonesia, 2011.

Tomatala, Yakob. Kepemimpinan Kristen Yang Dinamis. Jakarta: YT Leadership Foundation, 1997.

Baker, F. L. Sejarah Kerajaan Allah. Jilid 1. Jakarta: BPK Gunung Mulia, 1951.

Baker, F. L. Sejarah Kerajaan Allah. Jilid 2. Jakarta: BPK Gunung Mulia, 1958.

Maxwell, John C. Menjadi Orang Yang bepengaruh. Jakarta: Yayasan Pelayanan Tuaian Indonesia, 2001. 